\title{
Pediatric Sedation During Magnetic Resonance Imaging Procedures in Turkey
}

\author{
Türkiye'de Manyetik Rezonans Görüntüleme Sırasında Pediatrik Sedasyon
}

\author{
Güneș Orman', Ümit Aksoy Özcan², Mehmet Masum Șimșek \\ ${ }^{1}$ Haydarpasa Numune Training and Research Hospital, Radiology Clinics, Istanbul, Turkey \\ ${ }^{2}$ Acubadem University School of Medicine, Istanbul, Turkey
}

\begin{abstract}
AIM: We aimed to evaulate the daily practice of medical sedation in pediatric population during magnetic resonance imaging (MRI) procedures in Turkey.

METHODS: The study was performed by using a questionnaire consisting of eight multiple choice questions. A total of 250 radiologists were introduced to participate in the study by mail, fax or telephone.

RESULTS: A total of 165 of 250 radiologists from 28 different cities of Turkey participated. Sedation of pediatric patients during MRI procedures was a routine practice of 123 (74.5\%) of the participants, however 42 (25.5\%) of the participating radiologists did not have/use the facilities for sedation of the pediatric population. Our findings suggested that the anesthesiologists are the most frequently involved specialists during the sedation procedures (63\%) in Turkey.
\end{abstract}

CONCLUSION: Sedation during diagnostic procedures in pediatric population seems to be most frequently performed by the anesthesiologists in Turkey and pediatric sedation rate during MRI procedures is $74.5 \%$.

Key words: pediatric; sedation; magnetic resonance imaging

\section{ÖZET}

AMAÇ: Türkiye'de güncel pratikte magnetik resonans görüntüleme (MRG) sırasında pediatrik popülasyonda tıbbi sedasyon uygulamalarını araștırmayı amaçladık.

YÖNTEM: Çalıșma sekiz adet çoktan seçmeli soru içeren bir formun kullanımıyla yapıldı. Mektup, faks ya da telefon ile toplam 250 radyoloji uzmanı çalıșmada yer almak için davet edildi.

BULGULAR: Türkiye'nin 28 farklı șehrinden 250 radyoloji uzmanından 165 tanesi çalıșmaya katıldı. Katılımcıların 123 (\%74,5) tanesinin günlük pratiklerinde pediatrik hastalara MRG sırasında sedasyon uygulanıyordu, ancak $42(\% 25,5)$ katıımcı günlük uygulamada

Dr. Günes Orman, Haydarpasa Numune Eğitim ve Arastrma Hastanesi, Radyolöi Kliniği, Istanbul-Türkive, Tel.05334119206Email.gunesorman@yaboo.com

Gelis Taribi: 13.01.2013 • Kabul Taribi: 16.09.2013 sedasyon kullanmıyordu. Bulgularımıza göre Türkiye'de sedasyon ișlemleri sırasında en fazla sıkıkta (\%63) anestezi uzmanları yer alıyordu.

SONUÇ: Türkiye'de tanısal ișlemler sırasında sedasyon en fazla sıklıkla anestezi uzmanları tarafından uygulanıyor gibi gözükmektedir. MRG sırasında sedasyon uygulama oranı ise \%74,5'tir.

Anahtar kelimeler: pediatrik; sedasyon; manyetik rezonans görüntüleme

\section{Introduction}

Most of the patients experience difficulties of the conditions present during magnetic resonance imaging (MRI) including the remote location from the assisting personal, the unique features of the MRI device suite and individual variations ${ }^{1}$. With its higher imaging quality and harmlessness, MRI has gained a worldwide popularity and become a first line diagnostic tool in the diagnosis of many clinical situations. Moreover its demand is continuously increasing $^{2-4}$. However, the brutal noise in the scanning room, necessity of full immobility to gain optimal images during the procedure and the necessity for being in a narrow tubular space presents an uncomfortable condition for some patients. Particularly, some groups of patients including the children less than eight-year old, mentally retarded or claustrophobic adults require sedation during the procedure $e^{1,2}$.

The MRI unit is a work station where all processes have to be well planned and the staff must be trained to guarantee the patient safety, high imaging quality and cost effectiveness. In order to achieve optimal quality, appropriately trained, experienced and certified professionals, appropriate use of drugs 
individualized for each patient and sufficient monitoring are essential ${ }^{4}$. With careful consideration of the unique MRI environment and rigorous testing of monitoring equipment, MRI can be performed safely in sedated patients 5 .

Pediatric sedation has some precautions. A standardized approach is mandatory to provide safety of the child and the efficiency of the procedure. The child and his/her condition should be examined clinically and appropriate preparation like fasting before the procedure and individualized sedation plan would decrease the rate of complication and increase the success rate. Sedation is a continuum, and it can be easy to advance from one level to the next and even reach the state of general anesthesia ${ }^{6,7}$.

In spite of all its risks, in order to reveal high quality images, sedation during MRI in pediatric population is mandatory for most of the patients. In this study, we aimed to evaluate the current status of the pediatric sedation practice in Turkey. The determination of the contributing medical specialties and the rate of pediatric sedation in daily practice were the main concern of the study.

\section{Methods}

The study was performed between February and June 2010. Following the admittance to the local review board, 250 radiology specialists working in different regions of Turkey were introduced to participate.

A questionnaire form consisting of eight multiple choice questions were delivered to the participants by mail, fax or telephone and the filled forms gathered by the same delivery tools.

The questionnaire was designed to gather information dealing with the daily practice of pediatric sedation during MRI scanning. First part of the questionnaire included the data of the institute where the participant was working. The name, location, degree and owner (governmental or private hospitals) of the institutes were asked in that part. The second part of the questionnaire included the questions dealing with the daily practice of the pediatric sedation. The participants were asked to provide information about whether they have facilities for pediatric sedation, which sedation protocols they were using and which specialty was performing the sedation.

Statistical analysis was performed by using SPSS 16.0 packet program for Windows. The data was expressed with the number and the percentage of the participants. The data of the state and private hospitals was compared by using Mann Whitney U tests. A $\mathrm{p}$ value under 0.05 was considered significant.

\section{Results}

A total of 165 radiologists participated in the study by filling the questionnaire; however 85 of the introduced radiologists did not. The participants were living and working in 28 different cities of Turkey.

Of the 165 participants, 123 (74.5\%) had facilities for pediatric sedation in the hospital where they were practicing. However, 42 (25.5\%) of the participants declared that they did not perform sedation of pediatric patients in their hospitals.

Most of the participants $(128 ; 77.5 \%)$ were working in state hospitals and the rest $(37 ; 22.5 \%)$ was working in private hospitals. The comparison of the pediatric sedation practice in state and private hospitals was summarized in Table 1. According to the present data the daily practice did not differ between state and private hospitals $(\mathrm{p}>0.05)$.

Table 1. The comparison of the pediatric sedation practice in state and private hospitals

\begin{tabular}{|c|c|c|c|c|}
\hline The staff performing the pediatric sedation $(\mathrm{N}=165)$ & State hospital $(\mathrm{N}=128)$ & Private hospital $(\mathrm{N}=37$ ) & Total $(\mathrm{N}=165)$ & $p$ value* \\
\hline Anesthesiologist & $61(48)$ & $18(49)$ & $79(48)$ & 0.915 \\
\hline Pediatrician & $8(6)$ & $2(5)$ & $10(6)$ & 0.850 \\
\hline Radiologist & $6(5)$ & $2(5)$ & $8(5)$ & 0.858 \\
\hline Anesthesiologist + Pediatrician & $17(13)$ & $2(5)$ & $19(11)$ & 0.188 \\
\hline Anesthesiologist + Radiologist & $5(4)$ & $0(0)$ & $5(3)$ & 0.224 \\
\hline Pediatrician + Radiologist & $3(2)$ & $0(0)$ & $3(2)$ & 0.349 \\
\hline Anesthesiologist + Pediatrician + Radiologist & $1(1)$ & $1(3)$ & $1(1)$ & 0.348 \\
\hline Pediatric sedation is not performed & $27(21)$ & $12(32)$ & $39(24)$ & 0.154 \\
\hline
\end{tabular}


During pediatric sedation intravenous drugs were preferred in most of the cases. Only 14 of the participants mentioned the name of the used drugs during sedation and the mentioned drugs included IV midazolam, ketamine, dormicum, propofol, fentanyl, thiopental sodium, per os chloral hydrate, inhalant $\mathrm{N}$ protoxyte $\% 50$ with sevoflurane and isoflurane. Radiologists and pediatricians perform sedation with oral chloral hydrate.

\section{Discussion}

The data of our study obtained from 28 cities of Turkey suggested that pediatric sedation during MRI was performed in $74.5 \%$ of the hospitals. In addition the rate of pediatric sedation and the staff involved during sedation did not differ significantly whether the hospital was a state or private hospital. In both hospital groups, anesthesiologists most frequently perform the sedation procedure.

To our knowledge this is the first study dealing with the daily practice of pediatric sedation during MRI in Turkey. However, our sample included only 28 cities of the whole country. In addition, the data did not cover all of the hospitals situated in these cities. Moreover, there are some outpatient clinics which may be performing the procedures.

The reader should note that the obtained data was gathered from the responding radiologists. However, some of the hospitals do not have radiologists but may be performing pediatric sedation by the help of available staff like anesthesiologists, pediatrician and anesthesiology technicians.

Our study sample lacks of randomization and most of the country may not be sampled. Thus the results are vulnerable to bias. In addition, 165 of the predefined 250 radiologists filled the questionnaire and the loss of the data of the $34 \%$ of the participants increases the chance of bias.

With careful consideration of the unique MRI environment and with rigorous testing of monitoring equipment, MRI can be performed safely in sedated or anesthetized patients ${ }^{5}$. The MRI unit is a work station where all processes have to be well planned. The staff must be trained to guarantee the maximum safety of the patients, probable best quality of imaging and save expenditures. For optimal performance, trained, experienced and certified personnel, appropriate drugs and sufficient monitoring equipments are essential ${ }^{4}$.
Our study shows that the highest rate of sedation practice belongs to anesthesiologists. The finding may be related with the perception that anesthesiologists have the adequate experience and skills to sedate patients. Because sedation is a continuous procedure and may spontaneously develop into general anesthesia ${ }^{6,7}$. In addition, sedation of pediatric patients possesses some risks, such as hypoventilation, apnea, airway obstruction, laryngospasm, and cardiopulmonary impairment ${ }^{8}$.

During pediatric sedation anesthesiologists mostly prefer intravenous drugs like propofol and midazolam; however radiologists and pediatricians prefer oral agents like chloral hydrate. Orally used agents are perceived as not causing respiratory depression, however chloral hydrate may cause nausea and vomiting and the duration of the sedation is short. Consequently sedation may end up while the patient is still in the MRI scanner before the completion of the scanning process. Incomplete and inadequate sedation is more frequently observed in elder children. In these patients alternative sedation regimens, may be combined with chloral hydrate, may be preferable ${ }^{9}$. In addition, there are some reports of mild hypoxia and airway obstruction requiring endotracheal intubation in children received high doses of chloral hydrate as a sole sedative during CT scans ${ }^{10}$. Moreover, chloral hydrate may selectively depress genioglossus muscle activity and predispose to airway obstruction ${ }^{11}$. Thus, pediatric patients sedated by using chloral hydrate should be monitorized with a strict adherence to the available guidelines, such as the guideline of the American Academy of Pediatrics (AAP) $)^{12}$.

The safety of sedated children for diagnostic and therapeutic procedures has become an issue of concern during the past several years ${ }^{9}$. The safe sedation of children for diagnostic procedures requires a systematic approach that includes; no administration of sedating medication without the safety net of medical supervision; careful pre-sedation evaluation to determine the underlying medical or surgical conditions that would increase the risks, appropriate duration of fasting before the elective procedures, providing the balance between depth of sedation and risk for those who are unable to fast in emergency procedures, a focused airway examination for large tonsils or anatomic airway abnormalities that might increase the potential for airway obstruction, a clear understanding of 
the pharmacokinetic and pharmacodynamic effects of the medications used for sedation, as well as an appreciation for drug interactions, appropriate training and skills in airway management to allow rescue of the patient, availability of the age and size appropriate equipment for airway management and venous access, appropriate medications and reversal agents, sufficient numbers of people to carry out the procedure and monitor the patient, appropriate physiologic monitoring during and after the procedure, a properly equipped and staffed recovery room, recovery to pre-sedation level of consciousness before discharge from medical supervision and appropriate discharge instructions ${ }^{8}$.

A shortage of service providers, particularly anesthesiologists, was the most common barrier to the development of pediatric sedation services ${ }^{13}$. According to the study of Dalal et al. there were different approaches to achieve sedation or anesthesia. The goal of their program was to match a pharmacologic approach with appropriate trained personnel to monitor and, if necessary, intervene if the infant developed side effects after medication ${ }^{13}$.

To achieve diagnostic images during MRI examinations, patients need to lie still to avoid movement artifact. Thus, sedation in pediatric population is mandatory in most of the cases. Although alternative techniques to sedation are available for preparing children for MRI, they have not been fully evaluated $^{7}$. In one of the techniques the parents are told to prevent the infant falling asleep the night before the MRI scanning procedure. The infant is supposed to sleep just before the scanning starts. However, the infant may awaken during the scanning process and the data dealing with the quality, advantageous or feasibility of the technique is lacking. Although some of the radiologists mentioned that they did not observe the awakening of the infants during MRI scanning, the technique requires further studies to provide evidence for routine clinical application.

It seems that the practice of pediatric sedation during MRI procedures did not differ whether the procedure was performed in state or private hospitals. The finding may be explained by the shortage of skilled staff in both groups of institutes. In addition, the pediatricians and radiologists may lack the required skills for pediatric sedation.

In conclusion, sedation during diagnostic procedures in pediatric population seems to be most frequently performed by the anesthesiologists in Turkey and pediatric sedation rate during MRI procedures is $74.5 \%$.

\section{Conflict of interest disclosure}

The authors declared no conflicts of interest.

\section{References}

1. Gooden CK. Anesthesia for magnetic resonance imaging. Curr Opin Anaesthesiol 2004;17:339-42.

2. Işık B. Manyetik rezonans görüntüleme ve anestezi. Marmara Medical Journal. 2006;19:98-103.

3. Formica D, Silvestri S. Biological effects of exposure to magnetic resonance imaging: an overview. Biomed Eng Online 2004;3:11.

4. Schulte-Uentrop L, Goepfert MS. Anaesthesia or sedation for MRI in children. Curr Opin Anesthesiol 2010;23:513-7.

5. Holshouser BA, Hinshaw DB, Shellock FG. Sedation, anesthesia, and physiologic monitoring during MR imaging: evaluation of procedures and equipment. J Magn Reson Imaging. 1993;3:553-8.

6. Gozal D, Gozal Y. Pediatric sedation/anesthesia outside the operating room. Curr Opin Anesthesiol. 2008;21:494-8.

7. Edwards AD, Arthurs OJ. Paediatric MRI under sedation: is it necessary? What is the evidence for the alternatives? Pediatr Radiol 2011;41:1353-64.

8. American Academy of Pediatrics, American Academy of Pediatric Dentistry, Cote C J, Wilson S;Work Group on Sedation. Guidelines for monitoring and management of Ppdiatric patients during and after sedation for diagnostic and therapeutic procedures: an update. Pediatrics 2006;118:2587602.

9. Malviya S, Voepel-Lewis T, Tait AR. Adverse events and risk factors associated with the sedation of children by nonanesthesiologists. Anesthesia Analgesia 1997;85:1207-13.

10. Greenberg SB, Faerber EN, Aspinall CL, et al. High-dose chloral hydrate sedation for children undergoing MR imaging: safety and efficacy in relation to age. AJR Am J Roentgenol 1993;161:639-41.

11. Hershenson M, Brouillette RT, Olsen E, et al. The effect of chloral hydrate on genioglossus and diaphragmatic activity. Pediatr Res 1984;18:516-9.

12. Vade A, Sukhani R, Dolenga M, et al. Chloral hydrate sedation of children undergoing CT and MR imaging: safety as judged by American Academy of Pediatrics guidelines. AJR Am J Roentgenol 1995;165:905-9.

13. Dalal PG, Murray D, Cox T, et al.. Sedation and anesthesia protocols used for magnetic resonance imaging studies in infants: provider and pharmacologic Ccnsiderations. Anesth Analg 2006;103:8638. 